\title{
RE-USE OF AGRICULTURAL FACILITY BROWNFIELDS
}

\author{
Klara FROLIKOVA PALANOVA ${ }^{1}$ \\ ${ }^{1}$ Department of Architecture, Faculty of Civil Engineering, VSB-Technical University Ostrava, \\ Ludvika Podeste 1875/17, 70833 Ostrava-Poruba, Czech Republic
}

klara.frolikova@,vsb.cz

DOI: $10.31490 /$ tces-2018-0021

\begin{abstract}
The paper focuses on brownfields of agricultural facilities in three locations, i.e. in the center of a small village, on the outskirts of the village and in the countryside. Historical sites with cultural and social value were selected for their location, context and their nature or the existence of listed buildings. This created the opportunity to present three model situations of approaches to site solutions. The issues were gradually presented to Master's degree students in Architecture and Civil Engineering at the Faculty of Civil Engineering of $V S ̌ B-T U$ in Ostrava, to allow each of them to create an opinion over the course of the semester on the possibility and level of utilization of abandoned agricultural sites. The results of their work show their thinking on the direction and re-use of the brownfields, primarily influenced by their location, but also by other aspects that had a significant impact on the resulting design concept.
\end{abstract}

\section{Keywords} Depressing zone, brownfield, agricultural site,
conversions.

\section{Introduction}

When we speak of brownfields, we are usually referring to long-term unused industrial facilities and buildings [1]. Nevertheless, it is important to realize that this can also concern administrative, business and warehouse buildings, and, last but not least, also include agricultural sites, which make up a significant part of the villages and landscape of the Czech Republic. The facilities of Unitary Agricultural Cooperatives would certainly be a separate issue, but historic buildings and sites are also a significant part. Under the direction of prof. Petr Hrůša, doc. Martina Peřinková and Dr. Klára Frolíková Palánová, students of the architecture studio were gradually presented with three abandoned historic agricultural sites, which, above all, were differentiated by their location. The farmyard in Hukvaldy lies in close proximity to the center of the village, the Perštýn site in Litomyšl is on the outskirts of town and Boří dvưr $\mathrm{u}$ Valtic is situated in open landscape. The students were assigned to assess the functional purposes of the sites, the usability of the existing buildings, the integration of the particular facility into the context of place and to propose a specific design concept.

Giving the students a free hand in deciding on the functional purpose of the original facilities, a test case "residents" environment was created, whose preferences create one of the viewpoints for decision-making on the revitalization of brownfields [2]. The importance of the opinions of residents, as the possible future users of the sites, has been monitored and demonstrated over the long term by research at the Faculty of Agriculture and Economics of the University of South Bohemia and at Cardiff University in Great Britain [3], and therefore this aspect was also taken into account.

The students were also allowed to choose one of the possible approaches to the existing buildings on their own and design their reconstruction, demolition or a combination of the two options, with the possibility of additional construction or leaving open spaces. The general trend of demolishing brownfields in city cores, while preserving those on the outskirts or in open landscape [2] was not apparent in the small sample of students. Rather, there was a tendency toward preservation of historical monuments and other rare, unclassified buildings, that would surely command less importance among the lay public [4].

None of the brownfields under design consideration was perceived as an impediment to the development of the city [5]. On the contrary, in the designs, these sites once again become part of the city structure, or a full-fledged part of the landscape design of the Valtice facility. Sites within the city usually promote social contact.

The designs did not include the economic perspective, such as the increased value of localities in proximity to original brownfields, etc. [6], which in practice is certainly 
very important and included in the decision-making process and direction of the localities under design consideration.

\section{Three sites, three directions of functional purpose, three views on the re-integration and revitalization of brownfilds}

The first site is the farmyard in Hukvaldy, whose origins coincide with the time of establishment of the Hukvaldy castle in the 13th century. The existing buildings are, however, much more recent, having their origins in the mid-19th century. The site is located near the main thoroughfare of the village, in proximity to the church, town hall and the chateau. The extensive farmyard is enclosed on four sides by buildings, whereas one side consists of two-story buildings facing the main village road, and from which there is the main entrance to the area of design consideration. The rear part of the facility, on the other hand, opens into the landscape, formerly an orchard. The side buildings are contiguous with the surrounding development. The front buildings today are used as pubs and boarding houses, whereas the others have been abandoned for a long time, and the courtyard is unused. The facility is not readily apparent when passing through the village, nevertheless, residents view it as an impassable, non-functional barrier in a village without a town commons. Its proximity to the town hall and the lack of a town commons presents the potential for its main use as a cultural-social center of the village and a base for tourism, which is prevalent and supported in the village. A cultural base presents itself as more than appropriate in view of the fact that Hukvaldy is the birthplace of Leoš Janáček and every year a music festival, Janáčkovy Hukvaldy, is held here, and which is currently split among several locations. The social part would be designed for use by residents of the area as well as visitors. This functionality of the site would facilitate more integration of the site with the surrounding organism of the village, mainly for pedestrians, from multiple directions, such as from the main street as well as from the church and the lower parking lot. The part facing into the landscape mostly remains preserved for the view, not for regular movement of people, cars or as an entrance. This variation was designed by students in seven out of eleven cases, with various minor changes in the specification of component operations.

The remaining four students decided to return the farmyard to agricultural use, whether animal or plant production, and, in three cases, connected with agrotourism and research in one case. This variant led to designing the facility as enclosed, constrained and oriented inward to the farmyard. In two cases, the plan was to create an ornamental farmstead, whereas one version designing it as an animal production facility and the other a plant production facility. This would be supported by the composition and supplemented with smaller buildings, constrained by a protective bank or wall, with a strictly symmetrical courtyard and nearby garden. This design concept then specifies the differentiation of the functional purpose, tying the main entrance to the main street, which prepares the visitor for the special moment of a specific experience after entering the facility. In this case, the students propose calming of the thoroughfare, creating a town center on it, which will form the backbone of the village, upon which the important buildings will be contiguous, such as the farmyard under design consideration, the town hall, church, chateau and that will culminate in the main gate to the Hukvaldy castle park. The location of the site allows closing it off, without creating a significant barrier in the town.

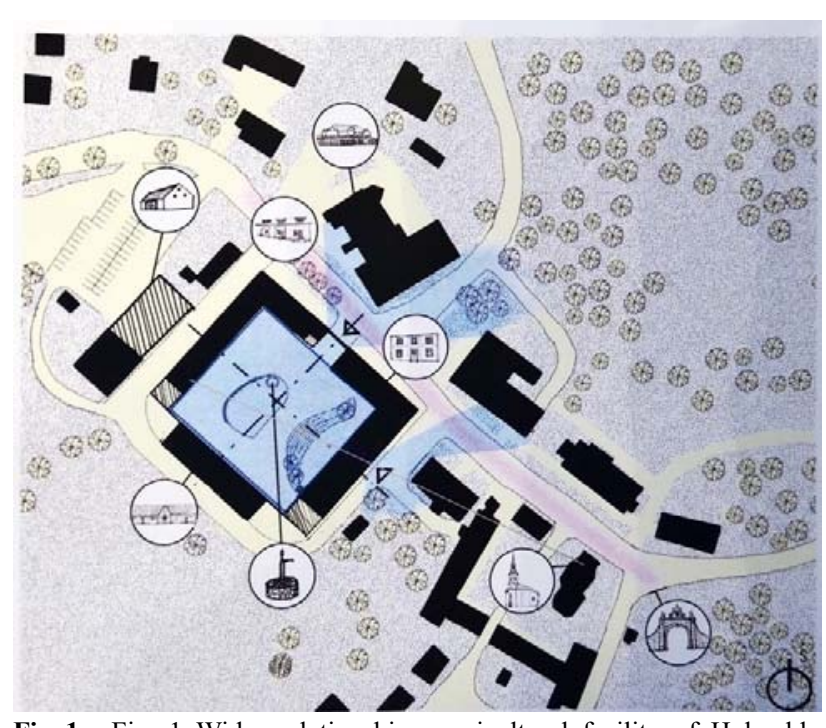

Fig. 1: Fig. 1 Wider relationships, agricultural facility of Hukvaldy (source: student design Bc. Michaela Kunrtova)

The second site is Perštýn in Litomyšl, with a listed baroque granary. In this case, the students differed in the number of uses for the original buildings. The center of interest has always been the granary. The site lies on the outskirts of the city and its integrity has been disrupted by the construction of the E35 main road across the plot, which it was necessary to deal with in the design concepts. The land is conveniently located near the exit from the city towards Hradec Králové. At present, two premises of the complex are used for housing (about 10 flats), the granary is not used, and the other buildings are then used as utility or storage spaces. The site is bordered on one side by the expressway, from the back by the Loučná River and from the city by the nurseries. The 16 th century complex is the only official brownfield in Litomyšl.

The most challenging task for students was to deal with the shape of the land disrupted by the expressway, and even its actual presence. On the other hand, they took advantage of the proximity of the Loučná river, where they extended the existing pedestrian and bicycle paths and connected the area to the distant historical center, so that the location was accessible in a way other than the car or nearby public transport. However, the location of the site 
and its distance from the historic center of the city determines it for functions suitable to the outskirts of town. The designs, therefore, primarily feature a shop connected with the possibility of parking, sport and recreation, mostly supplemented with housing units (5 variant solutions). In two cases the students proposed a residential complex, one a school of design and one of the designs proposed returning the site to its original purpose, i.e. agriculture, whereas a horse-breeding operation was located here. The core of the design solutions was then always the baroque granary, which became the central theme of all the designs. Its character predetermines it to a limited scope of use requiring minimal lighting, due to the small window openings. Mostly it was proposed for use as a gallery, cultural center, etc. The rate of utilization of other buildings and the approach to their preservation or demolition varied considerably among the students. In any case, even in the event of their demolition, the original ground plan, with minor variations, was respected when the site was completed, and the area is always designed as a closed, self-centered one. Due to the nature of the environment, which can be classified as a light industrial zone, this reaction is understandable. The only fact that the area raises over the surrounding areas of the craft and the light industry is the controversial E 35 expressway, which intersects the site, thereby making it conceivable as a gateway to the city, which in some cases, the students continued to develop.

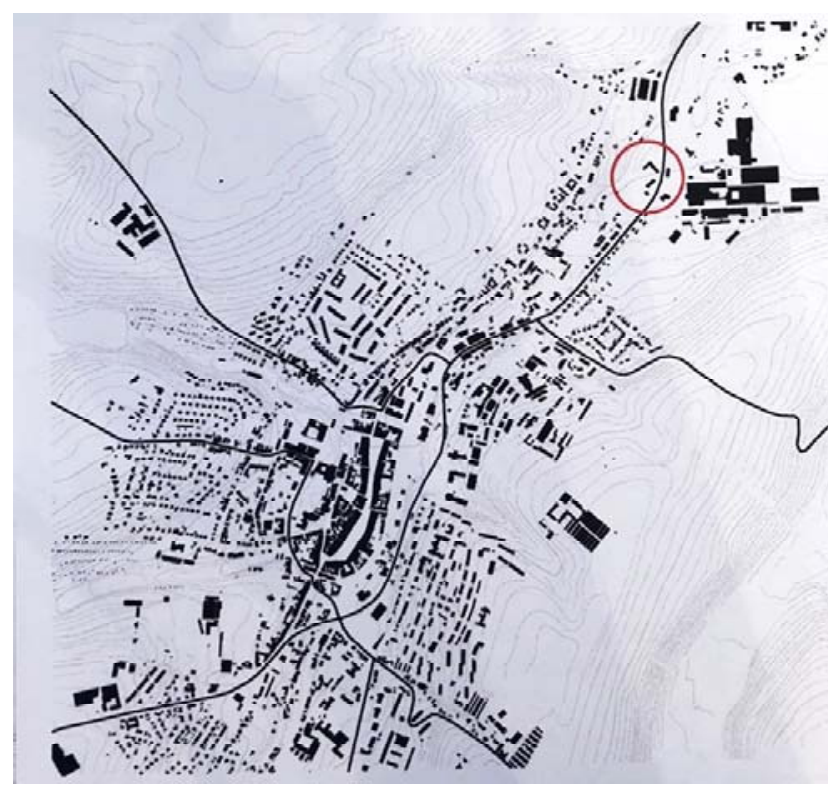

Fig. 2: Fig. 2 Perštýn site within the town of Litomyšl (source: student design Bc. David Eliáš)

The third facility is Boří dvůr at the Valtice site, built under the Liechtensteins. The original site, which still today is used for agricultural activities, though now reduced, is delimited by a composition of two perpendicular, tree-lined avenues, $5 \mathrm{~km}$ southeast of the Austrian border. Lengthwise buildings line an extensive courtyard, which is part of a landscape monument zone. Building on this fact, the students designed an ornamental farm which, with greater or lesser, or even zero use of the original buildings, creates a compositionally closed whole intended always for agricultural activity.

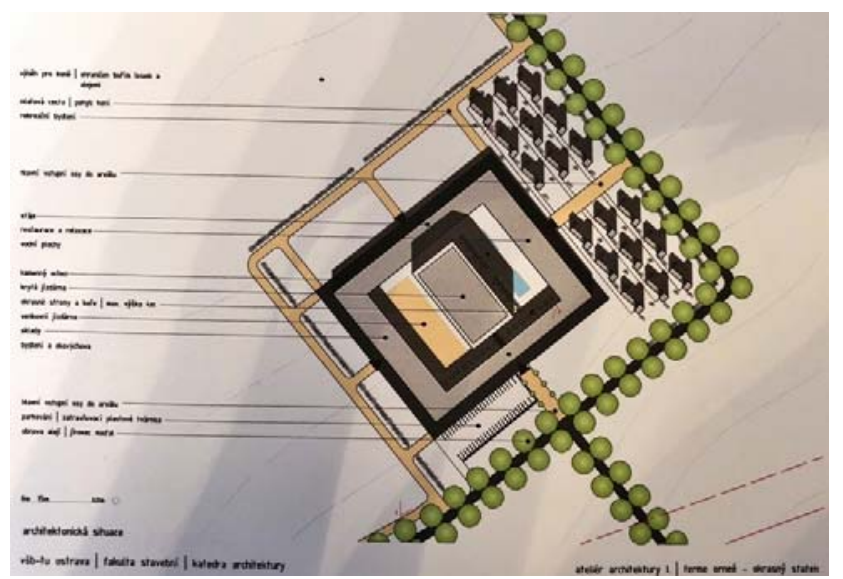

Fig. 3: Fig. 3 Design of the ornamental farm in the facility of Boří dvưr - layout (source: student design: Bc. Pavel Řihák)

\section{Conclusion}

Location was a primary factor in selecting the method of use of the revitalized site. While the site in the open landscape was restored, without exception, to its original purpose, the facility in the center of the village became a part of the village organism and fulfilling the missing town commons or other functions in the village. The site on the outskirts represents a gateway to the town, and here we find the greatest difference is its functional purpose, which, in its local color matches the choice of function to make it accessible by personal and public transport, or even as part of a hiking route, and it is not a common element of a city core or the landscape, or does not expressly demand such positioning.

Not even in one of the cases of the intravilan sites was there a total demolition of all the buildings, while in Boři Dvưr in a landscape subject to a strict composition, the landscape composition was predominantly respected. This initiated, in most cases, the proposal of complete demolition and rebuilding of a perfect, ornamental farm.

In comparison with the situation in Hukvaldy, agricultural activities are also considered in Litomyšl, and then only such activities in Boří Dvůr. While the originally enclosed facility in the center of the village, which the agricultural yards are, is perceived as a barrier and in most cases its integration into the village organism is accepted, most of the designs for the sites on the outskirts or in the countryside proposed enclosing the facility and turning its focus inward. All the designs for the site in the countryside expressly require it.

Specifying the functions, nature of the design concept, and defining the compositional design approach led to anchoring the original brownfields back within the organism of the villages and landscape so as to make them a full-fledged part. 


\section{Acknowledgements}

Work on the paper has been supported with funds from the conceptual development of science, research and innovation for the year 2018 allocated to VŠB-TUO by the Ministry of Education, Youth and Sports Czech Republic.

\section{References}

[1] KUNC, J. et al. Industrial legacy towards brownfields: Historical and current specifics, territorial differences (Czech Republic). Geographia Cassoviensis, Vol. 12, Issue 1, 2018, pgs. 76-91

[2] NAVRATIL, J. et al. Resident's preferences for urban brownfield revitalization: Insights from two Czech cities. Land Use Policy. Vol. 76, July 2018, pgs. 224234.

[3] MARTINAT, S. et al. Re-reuse of regenerated brownfields: Lessons from an Eastern European postindustrial city. Journal of Cleaner Production, Vol. 188, July 2018, pgs. 536-545.

[4] NAVRATIL, J. et al. Brownfields do not "only live twice": The possibilities for heritage preservation and the enlargement of leisure time activities in Brno the Czech Republic. Cities. Vol. 74, April 2018, pgs. 5263.

[5] VYSKOCIL, A. Textile industry in Brno: A case study of cultural heritage and the memory of an industrial centre. Muzeologia a kulturne dedicstvo. Vol. 5, Issue 1, pgs. 83-97.

[6] TURECKOVA, K. et al. How local population perceive impact of brownfields on the residential property values: Some remarks from post-industrial areas in the Czech Republic. Geographia Technica. Vol. 12, Issue 2, October 2017, pgs. 150-164.

\section{About Author}

Klara FROLIKOVA PALANOVA was born in Pelhrimov, Czech Republic. The study of architecture at the FA, VUT Brno and doctorate study at VŠB-Technical University Ostrava, where she works as an Assistant Professor, she runs Studio works and contributes to the theoretical lectures in the typology and theories of architecture. The Ph.D. study dealt with the aspects of the minimal housing, follow-up projects are aimed at ,living for eternity" - burying and funeral architecture.

Project investigator: VSB-TUO Student Grant Competition No. SP 2014/152: The issue of the principles of the concept of current cemeteries within the European background, their complexity and the specificities in the field of Architectural Design. No. SP 2015/62: The formation of the philosophical assumptions for the current absolute crematory architecture affecting modern methods and ethics of burying based on cremation. No. SP 2017/108: Mourning ceremonial hall as the place of communication in a secular environment from the second half of the 20th century in Bohemia and Moravia to the present.

Member of the project or project investigator: The conceptual development of science, research and innovation for the years 2016, 2017 and 2018 allocated to VSB-TUO by the Ministry of Education, Youth and Sports. 